\title{
PERAN NINIK MAMAK DALAM PENCEGAHAN DAN PENGURANGAN RESIKO PENYAKIT HIV/AIDS PADA REMAJA DI KOTA SOLOK 2019
}

\author{
Abd Gafar, Syahrum \\ Politeknik Kesehatan Kemenkes Padang
}

\begin{abstract}
To inhibit the increase and spread of HIV-AIDS, it is necessary to partnership between civil society, people with HIV-AIDS, government and the role of community leaders. In Minangkabau Ninik Mamak is obliged to educate nephews in the field of religion, customary values, culture in community life to be able to live harmoniously. Data from the Solok City Health Office with HIV-AIDS in 2019 amounted to 54 cases and 30 of them died. The purpose of this study is to find out how Ninik Mamak's role in the application of indigenous and cultural values to the prevention and reduction of the risk of HIV-AIDS disease in adolescents in solok city. This research uses qualitative methodology with a case study approach, data collected through in-depth interviews. The results of the study of most ninik mamak have not played a role in maximally applying and instilling the values of Indigenous and Cultural Minangkabau to the youth nephew about the prevention and reduction of the risk of HIV-AIDS disease. Ninik Mamak as an informal leader who has a close relationship with the nephew must provide motivation, direction, guidance, and teaching wisely and wisely to the nephew to do it in everyday life. Suggestions that Ninik Mamak increase its role and function to instill indigenous values and Minangkabau culture in the daily life of youth nephews as an awareness effort in the prevention and reduction of the risk of HIV-AIDS disease
\end{abstract}

Keywords:Ninik Mamak; Customs; Culture; HIV AIDS; Adolescents.

\begin{abstract}
Abstrak
Untuk menghambat peningkatan dan peyebaran HIV-AIDS perlu Kemitraan antara masyarakat sipil, penderita HIV-AIDS, Pemerintah dan peran tokoh masyarakat. Di Minangkabau Ninik Mamak berkewajiban mendidik kemenakan dalam bidang agama, nilainilai adat, budaya dalam kehidupan bermasyarakat untuk dapat hidup secara harmonis. Data Dinas Kesehatan Kota Solok penderita HIV-AIDS tahun 2019 berjumlah 54 kasus dan 30 orang diantaranya meninggal dunia. Tujuan penelitian ini untuk mendapatkan bagaimana peran Ninik Mamak dalam penerapan nilai-nilai adat dan budaya terhadap pencegahan dan pengurangan resiko Penyakit HIV-AIDS Pada Remaja Di Kota Solok. Penelitian ini mengunakan metodologi kualitatif dengan pendekatan studi kasus, data dikumpulkan melalui wawancara mendalam. Hasil penelitian sebagian besar Ninik Mamak belum berperan secara maksimal menerapkan dan menanamkan nilai-nilai Adat dan Budaya Minangkabau kepada kemenakan remaja tentang pencegahan dan pengurangan resiko penyakit HIV-AIDS. Ninik Mamak sebagai pemimpin informal yang memiliki hubungan dekat dengan kemenakan harus memberikan motivasi, arahan, bimbingan, dan pengajaran dengan arif dan bijaksana kepada kemenakan untuk melaksankannya dalam kehidupan sehari-hari. Saran agar Ninik Mamak meningkatkan peran dan fungsinnya untuk menanamkan nilai-nilai Adat dan Budaya Minangkabau dalam kehidupan sehari-hari kemenakan remaja sebagai upaya penyadaran dalam pencegahan dan pengurangan resiko penyakit HIV-AIDS.
\end{abstract}

Kata Kunci:Ninik Mamak; Nilai; Adat; HIV AIDS; Remaja

Penerbit: Poltekkes Kemenkes Padang, http://jurnal.poltekkespadang.ac.id/ojs/index.php/jsm 


\section{PENDAHULUAN}

Upaya pencegahan HIV/AIDS dapat berjalan efektif apabila adanya komitmen masyarakat, pemerintah dan peran aktif tokoh-tokoh masyarakat dalam memberikan pendidikan dan pengontrolan terhadap perilaku risiko tinggi yang dapat menularkan HIV/ AIDS tersebut di lingkungannya.Kasus HIV/AIDS yang terjadi Minangkabau (Sumatera Barat) mendapat perhatian yang serius, Data terbaru Desember 2018, mengutip pernyataan Wakil Gubernur Sumatera Barat Nasrul Abit menyampaikan, ada 1.860 orang yang kena HIV/AIDS di Sumatera Barat, lebih lanjut Nasrul menyatakan sekarang kasus tersebut tidak ada lagi ditutu-tutupi agar menjadi perhatian serius bagi semua pihak. Data yang didapatkan dari Dinas Kesehatan Kota Solok sampai bulan Juni 2019 ditemukan 54 kasus. Dari total 54 kasus tersebut 30 orang diantaranya telah meninggal dunia ${ }^{2}$. Berdasarkan data tersebut diatas dapat dikatakan bahwa penyebaran penyakit HIV/AIDS di Kota Solok apabila tidak dilakukan antisipasi dengan segera maka penyakit ini dengan cepat menyebar ke orang lain terutama remaja. Melihat faktor resiko penularan HIV/AIDS yang disebabkan oleh perilaku masyarakat, maka persoalan ini tidak hanya dikatakan sebagai masalah kesehatan semata, tetapi juga merupakan masalah sosial. Oleh karena itu diperlukan penanggulangan yang komprehensif. Penanggulangan HIV/AIDS di Indonesia bertujuan untuk memastikan tercapainya akses universal terhadap layanan pencegahan, pengobatan dan mitigasi dampak HIV/AIDS yang berfokus pada populasi kunci diantaranya remaja.

Prinsip-prinsip yang dipegang dalam penanggulangan tersebut adalah (1) Memperhatikan nilai-nilai agama, budaya serta norma sosial dan penghargaan terhadap manusia. (2) Merespon masalah sosial dan pembangunan, melibatkan pemangku kepentingan termasuk pemerintah dan masyarakat sipil. (3) Kemitraan antara masyarakat sipil, ODHA, pemerintah dan mitra pembangunan. (4) Dukungan sosial dan ekonomi yang berfungsi memberdayakan ODHA. Tujuan umum Strategi Rencana penanggulangan HIV dan AIDS tahun 2015-2019 ditujukan untuk percepatan pencapaian "3 Zero" (Zero infeksi baru, Zero kematian terkait AIDS dan Zero stigma dan diskriminasi) dengan cara mencegah penularan $\mathrm{HIV}^{3}$.

Untuk menunjang percepatan pencapaian Tri Zero tersebut, diperlukan adanya upaya kerjasama dengan melibatkan peran serta tokoh masyarakat salah diantaranya adalah Ninik Mamak. Minangkabau terkenal dengan peran seorang Ninik Mamak dalam mendidik dan menjaga garis keturunan terhadap kemenakannya ${ }^{4}$. Ninik Mamak di Minangkabau adalah seorang laki-laki dari suatu kaum yang dituakan dan jadi "tampek baiyo dan bamolah" artinya sebagai orang yang diajak untuk bermusyawarah walaupun ia masih muda ${ }^{5}$. Adat Minangkabauamat kaya dengan nilai luhur yang sejalan dengan nilai-nilai yang ada di Pancasila sebagai identitas bangsa. Sebagai subkultur (kebudayaan) bangsa, dengan filosofi ABS-SBK (Adat Basandi Syara'-Syara'Basandi Kitabullah), dioperasionalkan 
dengan SM-AM (Syara' Mangato-Adat Memakai) dan ATJG (Alam Terkembang Jadi Guru). Artinya adat Minangkabau adalah pelaksanaan agama (syara'). Dalam melaksanakan syara' yang bersumber al-Qur'an (Kitabullah) dan Hadis-hadis Nabi Muhammad Shalallohu Alaihi Wassalam,dibumikan dengan kepintaran membaca kearifan alam ${ }^{6}$.Ninik Mamak berperan membimbing kemenakan dalam bidang adat, bidang agama, dan bidang perilaku seharihari ${ }^{4}$. Oleh karena itu Dalam upaya pencegahan penyebaran HIV/AIDS ini sangat diperlukan peran Ninik Mamak secara aktif.

Penelitian ini bertujuan untuk mendapatkan gambaran bagaimana peran Ninik Mamak dalam pencegahan dan pengurangan resiko penyakit HIV - AIDS terhadap remaja di Kota Solok tahun 2019. Hasil penelitian ini sebagai masukan bagi Ninik Mamak serta lembaga nya dan Pemerintah Daerah sebagai tungku tigo sajarangan dalam membuat sebuah kebijakan yang berkaitan dengan Pencegahan dan Pengurangan Resiko Penyakit HIV / AIDS Pada Remaja Di Kota Solok Tahun 2019.

AIDS (Acquired Immune Deficiency Syndrome), adalah kumpulan gejala penyakit akibat menurunnya sistem kekebalan tubuh yang disebabkan oleh infeksi $\mathrm{HIV}^{7}$,dimanavirus HIV (Human Immunodeficiency Virus) ditularkan melalui hubungan seksual pria dengan pria, hubungan heteroseksual atau ditularkan melalui penggunaan satu jarum suntik secara bergantian. Selain itu, HIV juga ditularkan dari ibu penderita AIDS kepada bayi yang dikandungnya pada waktu proses kelahiran maupun melalui air susu ibu.Gejala orang yang terinfeksi HIV menjadi AIDS bisa dilihat dari 2 gejala yaitu gejala mayor yang umum terjadi seperti; berat badan menurun lebih dari 10\% dalam 1 bulan, Diare kronis yang berlangsung lebih dari 1bulan, Demam berkepanjang lebih dari 1 bulan, Penurunan kesadaran dan gangguan neurologis, dan Demensia / HIV ensefalopati. Upaya pencegahan penularan HIV yang paling efektif adalah dengan memutus rantai penularan yaitu dalam bentuk penyuluhan kesehatan ke sekolah dan masyarakat mengenai perilaku risiko tinggi yang dapat menularkan HIV, Tidak melakukan hubungan seks dengan berganti-ganti pasangan Menyediakan fasilitas konseling dan Tes HIV Sukarela yang disarankan kepada orang yang terkena salah satu faktor risiko, sehingga diketahui status infeksi serta dapat dilakukan pencegahan dan pengobatan sejakdini, begitu juga pencegahan penularan HIV dari ibu ke anak serta Melakukan tindakan kewaspadaan Universal bagi petugas kesehatan ${ }^{8}$.

\section{METODE PENELITIAN}

Penelitian ini adalah kualitatif dengan rancangan studi kasus, objek penelitian sebagai informannya Ninik Mamak dan Kemenakan remaja. Informan ditentukan dengan purposive sampling yaitu memilih sampel yang kaya dengan informasi, penelitian ini dilakukan di Kota Solok, pengumpulan data dilakukan dengan wawancara mendalam atau Indepth Interview, penelitian ini melakukan triangulasi sumber untuk mengkaji keabsahan data. Variabel 
penelitian Upaya Ninik Mamak dalam pencegahan dan pengurangan Resiko HIV AIDS melalui Pendidikan nilai Adat dan budaya.

Tabel 1. Defenisi Operasional

\begin{tabular}{lll}
\hline & Variabel & \multicolumn{2}{c}{ Defenisi Operasional } \\
\hline Upaya Ninik Mamak dalam & Suatu bentuk pengajaran yang diberikan oleh \\
pencegahan dan pengurangan & Ninik Mamak terhadap Kemenakan Remaja \\
Resiko HIV AIDS melalui & tentang bagaimana kemenakan remaja \\
penerapan nilai adat dan & berperilaku sesuai dengan nilai adat dan budaya \\
budaya & & Minangkabau terutama adat salingka nagari \\
& dalam rangka pencegahan dan pengurangan \\
& Resiko HIV AIDS
\end{tabular}

Unit analisis menggunakan conten analisis. yaitu analisis data menggunakan tahapan transkrip, koding, kategori, interpretasi, penarikan kesimpulan dan penyajian data secara naratif.

\section{HASIL PENELITIAN}

Sebagian besar Ninik Mamak belum berperan secara maksimal memberikan pendidikan nilai adat dan budaya dalam pencegahan dan pengurangan resiko penyakit HIV/AIDS pada remaja di Kota Solok. seperti yang diungkapkan oleh responden berikut ini :

"Kadangninikmamakinitidaksepakat, ada yang menyuruhada yang tidak" (Informan 2)

"Kalaudarisaya di kaumsaya, adajugasayaberikan tentang penerapan nilai adat itu,sayapantau. tapi memang tidak selalu, sayamemberikansosialisasi, kalausudahmenyimpangkemenakansaya, sayategur" (Informan 4)

"Pendidikan nilai nilai adat itu yang saya lakukan membatasi pergaulan anak muda sekarang, seperti kata petuah orang, malabiahan ancak-ancak, mangurangan sio-sio, babuek baiak pado-padoi, babuek buruak sakali jalan, a itu kan babuek buruak tu, jan sakali-sakali itu dikarajoan.” (informan 9)

"Kalau mengontrol yang namanya kamanakan itu, jujur saja masalahnya awak kini kan punya kamanakan banyak, kita tidak bisa lagi mendidik secara maksimal karena sudah diambil alih fungsinya oleh bapaknya, dimana kadang bapaknya juga seorang Ninik Mamak" (informan 11)

"Masalah Nilai-nilai adat ini hanya disampaikan saja, tanpa memberikan contoh, misalnya selama ini kami sekali sebulan ada itu arisan keluarga tiap bulan yang kadang rutin kadang tidak dilakukan".(Informan 14) 
"Bila bicara tentang nilai adat dan budaya ini, tidak ada hambatannya, akan tetapi yang jadi persoalan adalah penerapannya dan perealisasikannya yang kurang terutama oleh Ninik Mamak" (informan 17)

"saya sarankan ke anak kemenakan, jangan terpengaruh dari luar. Pengaruh global, karena kita sudah bercampur" (Informan 20)

"Kalau saya anak kemenakan saya arahkan ke surau dan kami hadir di situ sebagai ninik mamak untuk memberikan ilmu adat, supaya nantik ilmu itu tinggal di memorinya jadi dengan sendirinya nantik, apa yang di dapat di surau dia akan memperbanyak belajar di luar karena nantik dia akan menjadi ninik mamak" (Informan 25)

"Ada, karnasaya yang memberikanpembinaanadatdansyarat, setiappanggungarisansekalisebulan, disampaikan, ke guru-guru pidato, niniakmamak, anakkamanakankalaubiasdibimbingjangansampaimemakainarkoba" (informan 28)

\section{PEMBAHASAN}

Hasil wawancara mendalam dengan Informan Ninik Mamak yang telah ditranskrip terlebih dahulu oleh peneliti, keabsahan data juga dilakukan dengan cara trianggulasi., yaitu memeriksa kebergantungan dan kepastian data yang dilakukan tentang proses maupun hasil atau keluaran setelah dilakukan wawancara9 .

\section{Peran Ninik Mamak Dalam Kehidupan Sehari-Hari.}

Peranan Ninik Mamak ditengah-tengah masyarakat sebagai pemimpin informal dituntut untuk memotivasi anak kemenakan di berbagai kegiatan dalam pelaksanaan pembangunan fisik maupun non fisik $^{10}$. Mamak berkewajiban dalam mendidik dan membimbing kemenakan dalam bidang adat, bidang agama, dan bidang perilaku sehari-hari cara bergaul yang baik, pendidikan keterampilan atau kerumahtanggaan dan pendidikan formal lainnya. karena seorang Ninik Mamak mempunyai peranan yang kuat di rumah kaumnya, seperti ungkapan "kemenakan seperintah mamak" baik dalam urusan adat, harta warisan dan pernikahan ${ }^{11}$.

Dalam kebudayaan Minangkabau hubungan antara mamak dengan kemenakan merupakan suatu konsekuensi riil yang harus dilaksanakan oleh Ninik Mamak dengan arif dan bijaksana dalam memberikan arahan, bimbingan, dan pengajaran seperti yang diungkapkan dalam papatah adat "kaluak paku kacang balimbiang, tampuruang lenggang lenggokan, bawok manurun ka saruaso, tanamlah siriah jo ureknyo, anak dipangku, kamanakan dibimbiang, urang kampuang dipatenggangkan, tenggang nagari kabinaso, tenggang sarato jo adatnyo", (kaluk paku kacang belimbing, buahnya lenggang lenggokan, dibawa orang ke Saruaso, anak dipangku kemenakan dibimbing, 
orang kampung dipertenggangkan, jaga negeri jangan binasa, jaga juga beserta adatnya)

\section{Bentuk Penerapan Nilai - Nilai Adat Minangkabau}

Nilai adalah sebuah konsepsi yang dimiliki oleh seseorang tentang sesuatu yang diingini untuk mempengaruhi suatu tujuan atau tindakan karena nilai merupakan suatu konsep, yaitu hasil dari pembentukan mental yang dirumuskan dari tingkah laku manusia sehingga menjadi sejumlah anggapan yang hakiki, baik dan perlu dihargai sebagaimana mestinya ${ }^{12}$. Penerapan nilai-nilai adat Minangkabau dalam kehidupan sesuai dengan ajaran "raso dibaok naik, pareso diabok turun" yaitu apa yang dipikirkan dan ingin untuk dilaksanakan haruslah diuji kebenarannya dengan perasaan ${ }^{11}$. Ninik Mamak dalam kepimimpinannya hendaknya dilaksanakan dengan kebenaran dimana setiap perbuatan tindak tanduk ataupun perkataan mengandung kebenaran (Alua luruih). atau menurut limbago adat yaitu mungkin dan patut, contoh suatu perbuatan yang akan dilakukan harus dikaji dengan mungkin dan patutnya. Sedangkan apa yang dirasakan dan ingin pula untuk dilaksanakan hendaklah diuji dengan pikiran, karena pikiran Ninik Mamak haruslah menuju kepada jalan kebaikan untuk dirinya, untuk kemenakannya, kaum kerabat dan untuk orang banyak di dalam nagari, oleh karena itu setiap Ninik Mamak harus memikirkan dengan baik terlebih dahalu setiap kata yang akan diucapkan, setiap pekerjaan yang akan dilakukan, dengan kata lain wajib memikirkan baik buruk, untung rugi, mudharat manfaat suatu perbuatan, ini yang harus dimiliki oleh seorang Ninik Mamak, karena seorang Ninik Mamak adalah contoh tauladan bagi anak kemenakannya dan orang banyak.

Dalam pergaulan sehari-hari Ninik Mamak harus pandai meletakan sesuatu pada tempatnya, sehingga dia menjadi seorang pemimpin yang beribawa dan disegani. apabila Ninik Mamak telah berperilaku sesuai dengan nilai-nilai adat, maka dalam tatanan masyarakat Minangkabau jarang dijumpai adanya Ninik Mamak yang ditinggalkan oleh kemanakannya dalam membuat suatu keputusan. Akan tetapi kenyataan yang terjadi sekarang ini "raso jo pareso" sudah mulai kurang tertanam dalam jiwa seorang Ninik Mamak, sehingga kemenakan kurang menghargai Ninik Mamak, terjadi kemerosotan nilainilai moral dalam kehidupan sehari-hari kemenakan, seperti kata-kata kasar yang dilontarkan, pergaulan bebas, meningkatnya kenakalan remaja, penggunaan napza dan lain lain. sehingga segala persoalan yang timbul dalam lingkungan kaumnya tidak dapat diselesaikan dengan baik.

\section{Strategi Pembelajaran Nilai:}

Pendidikan nilai bukan hanya sekadar tambahan (pelengkap), melainkan merupakan sesuatu yang hakiki dalam seluruh proses pendidikan. Pendidikan nilai menjadi kian penting ketika arus Globalisasi, materialisme dan konsumerisme secara global terus mengikis nilainilai luhur dari kehidupan manusia, termasuk di Minangkabau, hal ini dapat kita lihat dimana 
kemenakan remaja kurang menghormati mamaknya, kemenakan remaja kurang menerapkan nilai-nilai adat yang seharusnya diperankan dalam kehidupan sehari-hari, seperti sopan santun, tata kerama pergaulan social, kemenakan kurang menurut titah atau perintah mamaknya. Pendidikan nilai akan lebih efektif jika dikembangkan lewat jalur nonformal karena disposisi kemenakan remaja akan terbangun dengan baik disposisi ini sangat ditentukan oleh faktor internal maupun eksternal. Faktor internal yang menentukan disposisi antara lain; niat, motivasi, dan arah konsentrasi perhatian. Sementara itu, faktor eksternalnya dinamika hubungan antar subjek yang terlibat ${ }^{13}$.

Untuk menerapkan nilai nilai dalam kehidupan kemenakan remaja, hendaknya prinsip yang harus diterapkan oleh Ninik Mamak adalah secara autonomi memberikan respek terhadap kemenakan yang dipandang sebagai persetujuan tanpa paksaan dan tindakan secara rasional, melakukan sesuatu yang baik sebagai pencegahan kesalahan atau kejahatan, Bersikap adil demi tercapainya kesamaan derajat dan keadilan terhadap kemenakan remaja yang menjunjung prinsip-prinsip moral, legal dan kemanusiaan, tidak menimbulkan cidera fisik dan psikologis pada kemenakan, berlaku jujur dengan penuh kebenaran, harus menepati janji untuk menghargai komitmennya terhadap kemenakan, taat dan setia terhadap keputusan yang telah disepakati.

\section{Pendidikan Nilai Adat Bermamak - Berkemenakan}

Nilai-nilai sosial budaya masyarakat Minangkabau dibuat selaras dengan nilai-nilai Agama. Nilai sosial ini menunjang masyarakatnya untuk dapat hidup secara harmonis dimana mereka berada. Kekuatan budaya Minangkabau merujuk nilai nan ampek yakni sopan santun, budi baik, baso indah. Dalam implemetasinya tercermin dalam tiga prilaku, yakni tuntas dalam substantif, tuntas dalam artikulasi, dan inklusifisme. Dampaknya akan terlihat dalampelaksanaan secara ideal yakni, pemimpin (nan gadang) dihormati, kamanakan (nan ketek/rakyat) disantuni, sesama pemimpin (samo gadang) lawan baiyo ${ }^{14}$.Semua nilai ini diperkuat sinergitas sistem nilai tali tigo sapilin dan tungku tigo sajaranganyaitu tiga unsur kepemimpinan di Minangkabau seperti Ninik Mamak, tuangkul ulamadan cadiak pandai ${ }^{6}$.

Nilai-nilai dalam kehidupan masyarakat Minangkabau tercermin dalam sopan, santun dimana masyarakat Minangkabau sebagai makhluk sosial tidak dapat melepaskan dirinya dari hidup bermasyarakat yang bertujuan untuk memperoleh keharmonisan dalam berinteraksi. Dalam interaksi ini perlu adanya tata krama, etika, sopan santun yang menjadi peganggan bersama dan sudah merupakan suatu norma yang harus dituruti dan diamalkan. Interaksi nilai-nilai adat Minangkabau diumpamakan seperti jalan. yaitu tau di jalan yang empat. Pertama jalan mendaki. maksudnya adalah bagaimana masyarakat Minangkabau bersikap dan bertindak sesuai dengan adat sopan santun terhadap orang yang statusnya lebih di tuakan baik dalam ikatan formal maupun non formal. contoh antara kemenakan 
dengan mamak. Kedua jalan menurun, yaitu sikap sopan dan santun dari yang tua atau yang dituakan baik dalam status maupun tingkat umur. Interkasi ini seperti ibu dan bapak kepada anaknya, kakak kepada adik, mamak kepada kemenakan. Ketiga Jalan mendatar, ini dikiaskan bila seseorang berinteraksi dengan sesama besar atau seusia, tingkah laku dan sopan santun bagi orang yang sebaya Keempat jalan melereng, tingkah laku dan sopan santun yang paling tinggi dalam situasi dan kondisi tertentu melalui kata kias seperti pantun, bidal, papatah petitih seperti berbicara dengan orang yang yang kita segani, hormati, contoh berbicara dengan Sumando (suami kakak atau adik) dan Ipar $^{14}$.

\section{Bentuk Pendidikan Nilai Adat Minangkabau}

Tidak dapat dipungkiri dalam tata kerama pergaulan sosial ditengah masyarakat bahwa Ninik Mamak adalah referensi utama dalam pergaulan oleh kemenakan dan masyarakat, karena Ninik Mamak adalah tauladan dalam kaumnya seperti kata pepatah adat minangkabau "kadiamba gadang, jo ka dijunjuang tinggi" artinya setiap perilaku atau gerak gerik Ninik Mamak akan menjadi rujukan dalam tata kerama, nilai dan norma, masyarakat Minangkabau menyebutnya dengan budi pekerti. orang yang berbudi adalah orang yang memakai adat sebagai pancaran dan cerminan kepribadiannya. orang berbudi adalah orang yang menanamkan rasa malu sebagai pakaian dalam pergaulan sehari-harinya. Masyarakat Minangkabau menjunjung tinggi nilai dan norma sebagai rasa malu yang sangat dalam, apabila rasa malu sudah tidak dimiliki lagi, maka orang tersebut akan sulit diterima dalam masyarakat.

Sebagai seorang pendidik Niniak Mamak akan selalu diminta pemikirannya, nasehatnya oleh anak kemenakan seperti kata pepatah "pai tampaek batanyo, pulang tampek babarito ${ }^{11}$.Ninik Mamak juga harus dapat memerankan diri seperti seorang guru sesuai dengan kata pepatah Nan kaditiru dan dituladani maksudnya adalah setiap perbuatan dan tingkah laku NinikMamak akan dicontoh dan diteladani oleh kemenakannya dalam tindakan dan perbuatan sehari-hari ${ }^{5}$. Maka dari itu Ninik Mamak harus membekali dirinya dengan ilmu yang luhur dan akhlak yang mulia, karena dalam memberikan pendidikan kepada kemenakan harus mempunyai sifat (1) bana jo luruih (benar dan lurus) (2) jujur dan dipicayo (jujur dan dipercaya) (3) cadiak jo pandai (cerdik dan pandai) yaitu memiliki ilmu pengetahuan yang cukup dan pandai mempergunakannya (4) fasiah babicaro (fasih berbicara) adalah lancar dalam bertutur kata, tidak kaku, tidak gugup dimana dia harus bisa menyampaikan sesuatu kepada kemenakannya dengan jelas dan lancar (5) panyaba (penyabar) maksudnya dapat menahan diri dan mengendalikan emosi ${ }^{15}$.Mamak tidak boleh berlaku berat sebelah harus adil dalam memberikan perlakuan. misal apabila ada diantara kemenakannya baik laki-laki maupun perempuan yang tidak menurut perintah atau ajaran mamaknya kepada jalan kebaikan dan kebenaran, seperti melakukan pergaulan bebas, suka keluyuran malam, konsumsi narkoba dan lain sebagainya sehingga menderita penyakit HIV AIDS, atau tindakan 
lain yang dapat mendatangkan aib bagi keluarga, mamak wajib mengajari dan menegur atas pebuatan kemenakannya itu atau menghukumnya dengan adil sampai mereka kembali kepada jalan kebenaran, bila tidak kuasa mamak wajib mengadukan kemenakannya itu kepada orang yang patut demi kebaikan kemenekannya itu.

Begitu juga sebaliknya kemenakan dalam bata-batas yang telah digariskan adat haruslah patuh pada mamaknya, dia wajib menurut titah atau perintah mamaknya menurut jalan yang adil dan lurus menurut adat karena adat mempunyai peranan penting di dalam hidup bermasyarakat, dimana adat itu adalah tata cara hidup dalam menyusun hubungan antar anggota masyarakat di Minangkabau. Seperti pepatah Minangkabau mengatakan "adat tak lapuak dek hujan, tak lekang dek paneh, artinya adat berbuhul mati dimana aturan-aturan adat yang tidak bisa dirobah-robah walau dengan kata mufakat sekalipun ${ }^{16}$, disamping itu adat Minangkabau mengutamakan budi, ini tercermin dalam petatah yaitu, Nan kuriak iyolah kundi, Nan merah iyolah sago, Nan baiak iyolah budi, Nan endah iyolah baso. Artinya bahwa masyarakat Minangkabau dalam berperilaku harus berbudi baik dan bahasa yang indah yang menjadi karakternya. Dalam ajaran Minangkabau budi pekerti yang baik itu menjelma pengamalannya melalui empat faktor yang disebut raso, pareso, malu, dan sopan. Raso ialah yang terasa oleh diri melalui panca indra manusia. Pareso ialah yang dirasakan oleh hati manusia. Malu ialah suatu sifat manusia. Sopan ialah tingkah laku atau tindakan yang mencerminkan budi pekerti.

\section{SIMPULAN DAN SARAN}

Sebagian besar Ninik Mamak belum berperan secara maksimal menerapkan dan menanamkan nilai-nilai Adat dan Budaya Minangkabau kepada kemenakan remaja tentang pencegahan dan pengurangan resiko penyakit HIV-AIDS. Ninik Mamak sebagai pemimpin informal yang memiliki hubungan dekat dengan kemenakan harus memberikan motivasi, arahan, bimbingan, dan pengajaran dengan arif dan bijaksana kepada kemenakan untuk melaksankannya dalam kehidupan sehari-hari. Disarankan kepada Ninik Mamak meningkatkan peran dan fungsinnya untuk menanamkan nilai-nilai Adat dan Budaya Minangkabau dalam kehidupan sehari-hari kemenakan remaja sebagai upaya penyadaran dalam pencegahan dan pengurangan resiko penyakit HIV-AIDS.

\section{DAFTAR PUSTAKA}

1. Data HIV AIDS di Sumbar Mengejutkan, Pemprov Siapkan Payung Hukum.http://m.gosumbar.com/. Published 2019.

2. Dinas Kesehatan Solok. Catatan Kasus HIV AIDS"Sampai Bulan Juni.(2019).

3. KOMISI PENANGGULANGAN AIDS NASIONAL. Strategi Dan Rencana Aksi Nasional Penanggulangan Hiv Dan Aids.; 2015. http://arc-atmajaya.org/wp- 
content/uploads/2013/07/Rencana Aksi Nasional Penanggulangan HIV dan AIDS Tahun 2010 2014.pdf.

4. Zakia R. Kesetaraan Dan Keadilan Gender Dalam Adat Minangkabau. J Gend Stud kafaah.org) Vol 1 No 1 (2011). 2011;1(1).

5. Muhammad J. Dilema Pemangku Adat Minangkabau "Sebuah Realita Kepemimpinan Ninik Mamak Kini. Bukit Tinggi: Cinta Buku Agency Bukittinggi; 2015.

6. Yulizal Y. Budaya Minangkabau dan Nilai Kepemimpinan Ninik Mamak .Makalah disampaikan sebagai nara sumber pada "Pelatihan Pemangku Adat Baru Diangkat se Sumatera Barat. 2012. http://yuyucenter.blogspot.com/2013/11/budaya-minangkabaudan-nilai.html.di download Kamis tgl 12-12-2019.

7. Irwan. Kearifan Lokal Dalam Pencegahan HIV/AIDS Pada Remaja. Gorontalo: Ideas Publishing; 2017.

8. Najmah. Epidemiologi Penyakit Menular. jakarta: Trans Info Media; 2016.

9. Sugiyono. Metode Penelitian Kuantitatif, Kualitatif Dan R\&D. Jakarta: Alfhabeta; 2011.

10. Bahardur I. Lokal Budaya Minangkabau Dalam Seni Pertunjukan Tradisional Randai STKIP PGRI Sumatera Barat. J Kaji Sastra, 7 (2), 145-160. 2018;7. https://doi.org/10.26499/jentera.v7i2.932).

11. Syahrul N. PERAN DAN TANGGUNG JAWAB MAMAK DALAM KELUARGA: TINJAUAN TERHADAP NOVEL SALAH ASUHAN KARYA ABDOEL MOEIS. J Penelit Sastra. 2017;10(1).

12. Yohanis. Pembinaan Nilai - Nilai Adat Basandi Syarak, Syarak Basandi Kitabullah Oleh Ninik Mamak Terhadap Anak Kemenakan Di Kenagarian Situjuah Gadang Kec Limo Nagari Kab.Lima Puluh Kota. jurnal.ensiklopediaku.org. 2020;2(2).

13. Munir M. NILAI-NILAI PENDIDIKAN DALAM PETATAH PETITIH ADAT MINANGKABAU (Alternatif Membangun Pendidikan Berkarakter). J Huk Islam. 2018;14(1).

14. Fimansyah W. Internalisasi Pendidikan Karakter Berbasis Kearifan Lokal Minangkabau Untuk Generasi Muda Buddayah. J Pendidik Antropol. 2020;2(2):97-104. https://jurnal.unimed.ac.id/2012/index.php/bdh .

15. Chaniago P. Dakwah Berbasis Konten Lokal: Analisis Ceramah Adat Basandi Syarak, Syarak Basandi Kitabullah. J IIm SYIAR Jur Dakwah, FUAD, IAIN Bengkulu. 2020;20(02):176-191. https://ejournal.iainbengkulu.ac.id/index.php/syiar.

16. Trimilanda AS, Desriyeni. PURWARUPA ENSIKLOPEDI ADAT PERKAWINAN MINANGKABAU. J Ilmu Inf Perpust dan Kearsipan. 2018;7(1). 